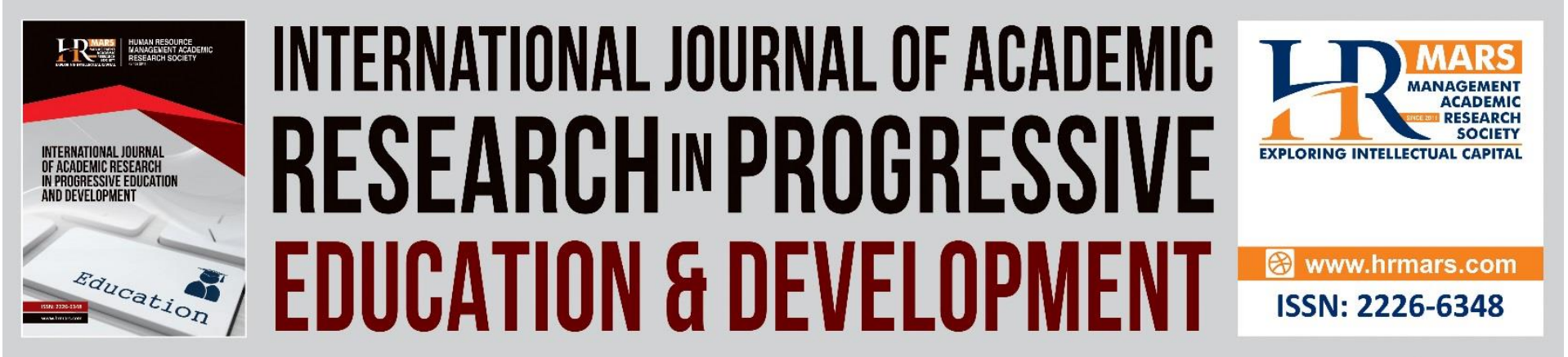

\title{
Applicability of M-Learning for Basic Arabic Language among Students During Distance Learning
}

Mohd Firdaus Yahaya, Zulazhan Ab. Halim, Muhammad Sabri Sahrir, Mohd Fauzi Abdul Hamid, Khoirun Nisak Mat Saad

To Link this Article: http://dx.doi.org/10.6007/IJARPED/v10-i3/11264

DOI:10.6007/IJARPED/v10-i3/11264

Received: 05 June 2021, Revised: 10 July 2021, Accepted: 29 July 2021

Published Online: 23 August 2021

In-Text Citation: (Yahaya et al., 2021)

To Cite this Article: Yahaya, M. F., Halim, Z. A., Sahrir, M. S., Hamid, M. F. A., \& Saad, K. N. M. (2021). Applicability of M-Learning for Basic Arabic Language among Students During Distance Learning. International Journal of Academic Research in Progressive Education and Development, 10(3), 827-843.

Copyright: (C) 2021 The Author(s)

Published by Human Resource Management Academic Research Society (www.hrmars.com)

This article is published under the Creative Commons Attribution (CC BY 4.0) license. Anyone may reproduce, distribute, translate and create derivative works of this article (for both commercial and non-commercial purposes), subject to full attribution to the original publication and authors. The full terms of this license may be seen at: http://creativecommons.org/licences/by/4.0/legalcode

Vol. 10(3) 2021, Pg. $830-843$

http://hrmars.com/index.php/pages/detail/IJARPED

JOURNAL HOMEPAGE

Full Terms \& Conditions of access and use can be found at http://hrmars.com/index.php/pages/detail/publication-ethics 


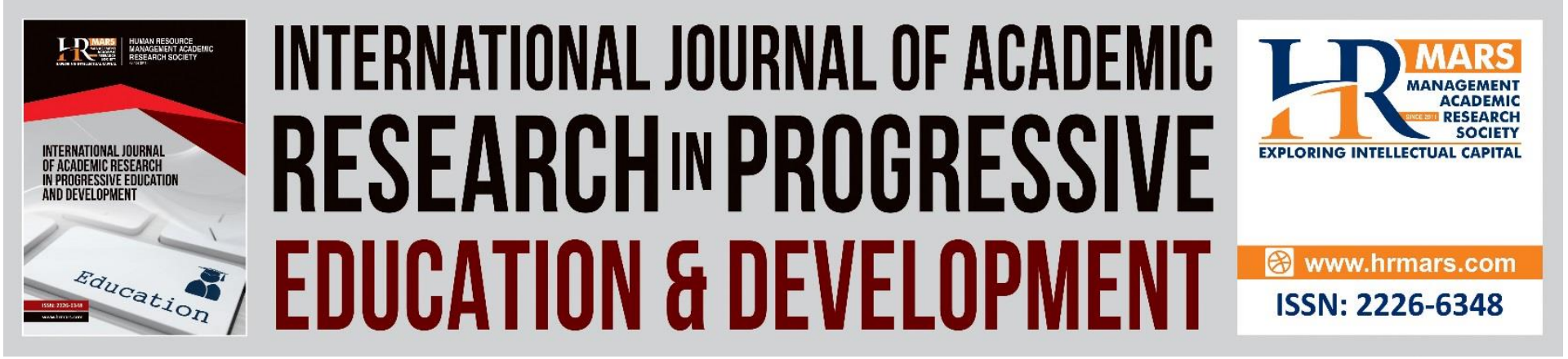

\title{
Applicability of M-Learning for Basic Arabic Language among Students During Distance Learning
}

\author{
Mohd Firdaus Yahaya ${ }^{1}$, Zulazhan Ab. Halim¹, Muhammad \\ Sabri Sahrir², Mohd Fauzi Abdul Hamid', Khoirun Nisak Mat \\ $\mathrm{Saad}^{3}$ \\ ${ }^{1}$ Faculty of Languages and Communication, Universiti Sultan Zainal Abidin (UniSZA), \\ ${ }^{2}$ Kulliyyah of Education, International Islamic University Malaysia (IIUM), ${ }^{3}$ Centre for \\ Fundamental Studies, Universiti Sultan Zainal Abidin (UniSZA) \\ Email: zulazhan@unisza.edu.my
}

\begin{abstract}
One of the emerging strategies in education is the usage of mobile devices (PdP). Following this line of thought, Arabic courses make a point of emphasising the use of $\mathrm{m}$-learning in $\mathrm{PdP}$ at the fundamental level. Due to the Covid-19 epidemic, this study was done to investigate at the most basic level - the applicability of Arabic m-learning among students on distance learning. The research involved 147 individuals who were enrolled in basic Arabic language classes. The students were satisfied with the application of mTasheel in the PdP process, according to the findings. The studies also revealed that Google platforms like Docs, Slides, and Sites were among the best and most dependable applications to utilise during PdP sessions during distance learning especially during the Covid-19 pandemic.
\end{abstract}

Keywords: M-Learning, Arabic Language, Covid-19, Distance Learning

\section{Introduction}

Today, technology is rapidly advancing, particularly in the mobile technology business; it is considered as advantageous not only in the fields of technology and communication, but also in the fields of learning and teaching (PdP). Laptops, PDAs, tablets, and mobile phones can all be used to access mobile technology from anywhere. Mobile devices are now among the most widely utilised in the globe, with the majority of tertiary students using them (Sundram, 2017). A mobile phone is a piece of technology that combines computers, notes, audio and video players, multimedia, phone, and messaging capabilities. This technology allows people to engage and get information more easily.

Furthermore, the concept of sharing can be simply accomplished via a mobile device. This gadget can also be used as a substitute for books, as it produces smaller and easier-tocarry notes. In reality, depending on the storage capacity of the mobile phone, it can hold thousands of electronic books or notes. With the capabilities and benefits offered by this 
mobile phone, it is expected to meet the needs of m-learning both now and in the future (Kukulska-Hulme \& Shield, 2008). According to prior study, learning through mobile devices can assist students enhance their degree of mastery in learning (Hao et al., 2019; Yafei \& Osman, 2016), as well as raise their interest in PdP activities PdP (Husin et al., 2017; Ab Ghani \& Baharudin, 2016).

Teachers and universities are attempting to employ online learning technologies to help students learn faster by using online learning sites similar to those used by most other institutions of higher learning. Students currently consider the usage of existing technologies to be insufficient. The dissemination of contemporary educational technological advancements is geared toward assisting students in acquiring the fundamentals of Arabic through the production of mobile phone applications. Mobile phones enable students to access Arabic language learning materials at any time and from any location. Furthermore, employing mobile learning medium in the lecture room or after completing the formal learning process outside the lecture room might assist students in reviewing Arabic language learning. Learning Arabic is more of a self-study endeavour.

\section{Problem Statement}

Findings of previous studies showed that among the difficulties students encountered is to master grammar (Che Mat \& Soon, 2010). In addition, factors such as of lack of learning support materials, limited time, lack of technology use in PdP are also factors that contribute towards student difficulties (Ramli, 2017; Ab Majid, 2017; Othman \& Ismail, 2013; Jalil, 1993) to master the Arabic language. Among the problems often encountered in the Arabic PdP process were; i) teacher-centered $\mathrm{PdP}$, ii) limited learning support materials and iii) lack of activities in PdP.

Arabic PdP is still seen using traditional methods such as "chalk and talk" or teacher centered. Teachers are the primary source for the delivery of PdP information in this approach, while students listen to lectures delivered by teachers from the beginning until the end of the classroom session (Sulaiman \& Abdul Wahid, 2021; Samah, 2012). Che Mat and Soon (2010) suggested other approaches that can have a positive impact on students compared to the traditional teacher-centered method. In addition, there is a lack of support materials in Arabic PdP that are characterised by technologies such as the use of multimedia elements and electronic learning in Arabic PdP. This shortcoming is due to the tendency of teachers to use traditional methods as opposed to the use of the latest teaching aids (Osman, 2017), only focusing on the use of textbooks in the classroom (Zaini et al., 2017). Next, the lack of PdP activities for Arabic language skills were seen as one of the factors contributing to students 'lack of interest in learning Arabic (Samah, 2012). Arabic PdP activities can be divided into two types, namely in-class activities such as quizzes, drills and extracurricular activities such as language camps, debates, speeches, storytelling, acting, poetry recitation, and visits ( Omar et al., 2016; Abdul Ghani et al., 2010).

\section{Technology and Education}

The rapid current of technology affects the PdP method today and it is different from the way it used to be. This change is due to the rapid changes in technology, rendering the old technology a few years ago to quickly become obsolete. The current trend of technology use among students is one of the factors that needed teachers and students to utilise technology in PdP (Yahaya et al., 2016; Goi \& Ng, 2009). The use of this technology are needed to be 
implemented across all fields including education and especially the field of language starting from the school level to institutions of higher learning.

Among the methods that are often used in PdP at all levels of education is the e-learning approach with the use of multimedia (Nasir et al., 2016).This is because the use of multimedia supports PdP presentation by using words and pictures in electronic form as well as attractive graphics for engaging in language teaching through the internet (Jolliffe et al., 2012; Sahrir \& Yusri, 2012). The next method is the PdP approach in the form of mobile or m-learning using mobile smart devices such as smartphones, tablets and laptops. This is due to several factors that drive the use of mobile phones such as the price of mobile phones becoming more affordable (A.Rahim, 2013; Siraj, 2004), social influence and ease of use (Hamdan et al., 2012). Even today's generation spends more time with the use of mobile phones and they use their mobile phones for various affairs whether to search for information and play with games in the phone (Yaman, 2016; Lim, 2014).

In addition, the utilisation of technology in language PdP is able to build a better learning environment (Abdul Ghani \& Wan Daud, 2018)as well as supporting language education materials in electronic form such as electronic exercise books, digital videos, interactive listening tests, online reading material for use with proper methods (Gill, 2006). The positive development of the utilisation of technology available today made it appropriate for Arabic $\mathrm{PdP}$ to utilise the technology in line with the current use. Interesting and interactive teaching materials will be able to attract the interest and motivation of students to learn Arabic easily and effectively. In addition, with the comprehensive utilisation of information technology in $\mathrm{PdP}$, it is able to improve the skill level of students to get information related to learning more quickly and easily. Figure 1 shows the progress of the PdP method from the past to the present.

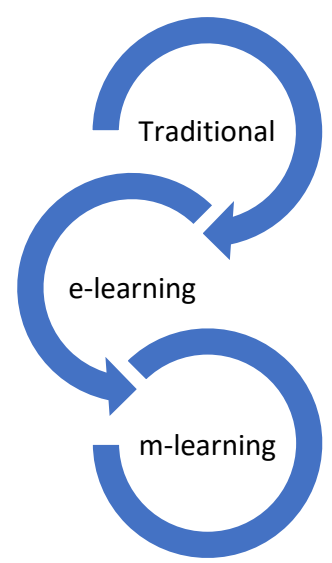

Figure 1: Evolution in the Learning and Teaching Process

\section{M-Learning}

There are several definitions of m-learning that cover various aspects. Some opinions say $\mathrm{m}$ learning is an evolutionary process from e-learning and blended learning ) (Sølvberg \& Rismark, 2012; Hussin et al., 2012) while other opinions claimed it is a new phenomenon that dominates communication systems nowadays (Nguyen, 2015). M-learning is defined as education and training that utilises ICT, individualised, flexible, collaborative learning with the community, teachers, facilitators and experts (Kim et al., 2013). According to Ally dan PrietoBlázquez (2014), m-learning requires highly motivated students and gives high commitment to learning which in turn produces more creative, multitasking students and they move 
towards do-it-yourself generation in developing their own learning methods. M-learning is information and communication technology (ICT) assisted learning that uses wireless mobile devices to enable learning to occur anytime and anywhere, especially the latest mobile devices such as PDAs, mobile phones and laptops (Siraj, 2004). Based on the definition presented, it can be concluded that m-learning is a personal learning, requiring high commitment from students in the learning process with the goal of facilitating the learning process in education.

\section{Objective}

This study was conducted to evaluate the applicability of basic level Arabic language mlearning support materials based on the following objectives:

a) Identify students' views on the content, design and usability of mTasheel.

b) Impact of mTasheel on learning based on students' views.

Use of Arabic Language M-Learning Support Materials

Several studies have been conducted using mobile phones or m-learning in learning foreign language vocabulary. Past studies have found that the use of mobile phones during the learning process is an effective approach which in turn can increase knowledge (Hao et al., 2019; Wu, 2014; Agca \& Özdemir, 2013) and student motivation (Husin et al., 2017). Samu (2012) also suggested that a study be conducted on subjects that do not integrate with technology. This is in line with the findings of several studies that say the use of ICT materials is less in Arabic language learning (Samah, 2012; Saad et al., 2005). There are also studies that suggest that the content of m-learning courses be developed for topics, or specific courses for undergraduate students so that the learning process becomes more effective (Dahaman, 2014).

To address the problems raised earlier, the use of learning support materials in the form of mobile devices is seen to be able to help students to increase their interest and motivation in learning. Learning using $\mathrm{m}$-learning is a form of student-centered learning and requires the students themselves to be active in seeking information and the role of the teacher is to be a facilitator to the learning session (Sopian, 2017; Yahaya et al., 2017; Samah, 2012). Reliance on textbooks can also be reduced as students gain access to mobile learning support materials using the mobile devices they have. This developed support material incorporates multimedia elements in learning such as text, images, audio and video. Besides, internal language activities can be carried out by increasing drills and quizzes so that students can carry out the process of self-learning at the time and place they need. Thus, this study will produce a supportive learning module in mobile form to help students learn basic Arabic language at UniSZA. This module will integrate elements of mobile technology to enable students to take advantage of PdP sessions and self-directed learning.

\section{Methodology}

Evaluation was conducted to gauge the usability of m-learning support materials at the basic level of Arabic. The total sample involved in phase three was a total of 147 students who took basic Arabic language courses at UniSZA. A questionnaire that was adapted from the previous study was used to assess the applicability of mTasheel. The instruments in this phase will first be reviewed before being distributed to the respondents. A total of three panel of instrument construction experts will be involved in the instrument review in this study. Then, a pilot test 
was conducted on 30 students using Alpha Cronbach's analysis to determine the internal consistency. The questionnaire in the study for this phase contained five sections, namely respondent demographics, content, design, usability and mTasheel impact. After being answered by students, the questionnaire was analysed using SPSS software to obtain Cronbach 's Alpha values as shown in Table 1.

Table 1: Cronbach's Alpha values for the pilot study of the questionnaire

\begin{tabular}{clc}
\hline No. & Construct & $\begin{array}{c}\text { Alpha Cronbach } \\
\text { Value }\end{array}$ \\
\hline 1 & Content & 0.918 \\
2 & Design & 0.916 \\
3 & Usability & 0.914 \\
4 & Impact & 0.900 \\
\hline
\end{tabular}

Pallant (2020) stated that high Cronbach's Alpha values indicate a high level of reliability. The selected value is 0.8 and above. In the context of this study, the Cronbach's Alpha values obtained were high and acceptable. Data from the questionnaires were analysed using SPSS software to obtain the mean value, standard insertion. The mean values were then interpreted as shown in Table 2.

Table 2: Mean interpretation table

\begin{tabular}{cc}
\hline Mean Score & Interpretation \\
\hline $3.67-5.00$ & High \\
$2.34-3.66$ & Moderate \\
$1.00-2.33$ & Low \\
\hline
\end{tabular}

\section{Findings and Discussion}

A total of 147 students were involved in the mTasheel usability assessment study. They were undergraduate students who were in the first semester at UniSZA. The students included 40 male students and 107 female students from 12 different study programmes. A summary of the demographic information of these students was summarised in Table 3. 
INTERNATIONAL JOURNAL OF ACADEMIC RESEARCH IN PROGRESSIVE EDUCATION AND

DEVELOPMENT

Vol. 10, No. 3, 2021, E-ISSN: 2226-6348 @ 2021 HRMARS

Table 3: Respondents Demographic Information

\begin{tabular}{llc}
\hline & & Frequency \\
\hline Gender & Male & 40 \\
& Female & 107 \\
\cline { 2 - 3 } Programmes & Total & $\mathbf{1 4 7}$ \\
\cline { 2 - 3 } & Bachelor English and Communication & 10 \\
& Bachelor of Dietetics & 4 \\
& Bachelor International Relations & 3 \\
& Bachelor Social Work & 9 \\
& Bachelor Medical Imaging & 3 \\
& Bachelor Islamic Finance & 29 \\
& Bachelor Accountancy & 1 \\
& Bachelor Medicine and Surgery & 21 \\
& Bachelor Biomedical Science & 6 \\
& Bachelor Nutritional Science & 9 \\
& Bachelor Social Science & 41 \\
& Bachelor Manufacturing Engineering & 11 \\
\hline & Technology & $\mathbf{1 4 7}$ \\
\cline { 2 - 3 } & Total &
\end{tabular}

\section{Content}

The mean interpretation of mTasheel content stated in Table 4 based on the views of the respondents showed that it was at a high level with an average mean value of 4.565 and a standard deviation of 0.578 . The highest mean score in the content construct was item B3 'Visual form content in Google Slides appropriate to student level' ( $M=4.63, S P=0.511$ ) followed by items $B 7$ 'Exercises related to the topic test students' comprehension' $(M=4.61$, $\mathrm{SP}=0.568)$ and $\mathrm{B} 8$ 'Module content can improve learning performance' $(\mathrm{M}=4.61, \mathrm{SP}=0.556)$. While the mean interpretation score that obtained the lowest value was item B2 'Language used is easy to understand' ( $M=4.46, S P=0.644)$. In general, the content construct recorded a high level of mean interpretation.

Table 4: mTasheel Content Analysis

\begin{tabular}{|c|c|c|c|c|}
\hline & mTasheel Content & Mean & SP & Interpretation \\
\hline B1 & Concise and clear learning content. & 4.56 & .524 & High \\
\hline B2 & The language used is easy to understand. & 4.46 & .644 & High \\
\hline B3 & $\begin{array}{l}\text { Visual form contents in Google Slides are } \\
\text { appropriate to the student's level }\end{array}$ & 4.63 & .511 & High \\
\hline B4 & $\begin{array}{l}\text { Audio form contents in Google Slides are } \\
\text { appropriate for the student's level }\end{array}$ & 4.55 & .551 & High \\
\hline B5 & $\begin{array}{l}\text { The content of the module corresponds to the time } \\
\text { allotted. }\end{array}$ & 4.56 & .609 & High \\
\hline B6 & $\begin{array}{l}\text { The training provided is appropriate to the student's } \\
\text { level }\end{array}$ & 4.54 & .664 & High \\
\hline B7 & $\begin{array}{l}\text { Exercises related to the topic test students' } \\
\text { comprehension. }\end{array}$ & 4.61 & .568 & High \\
\hline \multirow[t]{2}{*}{ B8 } & Module content can improve learning performance. & 4.61 & .556 & High \\
\hline & Average & 4.565 & 0.578 & High \\
\hline
\end{tabular}




\section{mTasheel Design Construct}

Table 5 showed the mean interpretation of the design construct based on the views of the respondents. The findings showed that the mTasheel design is at a high level with a mean value of 4.593 and a standard deviation of 0.56 . The item that recorded the highest mean value score was C3 'Images used help students to better understand the content' ( $M=4.67$, $\mathrm{SP}=0.487)$ followed by item $\mathrm{C} 1$ 'mTasheel design is attractive' $(M=4.63, \mathrm{SP}=0.511)$. The third position is item C9 'Google applications used are appropriate' ( $M=4.62, \mathrm{SP}=0.553)$. Two items received low scores, namely item C6 'Easy to read writing type' ( $M=4.54, S P=$ 0.588 ) and $C 7$ 'Clear and understandable information presentation design' ( $M=4.54, \mathrm{SP}=$ 0.599). In general, the design constructs recorded a high level of mean interpretation.

Table 5: mTasheel Design Construct Analysis

\begin{tabular}{|c|c|c|c|c|}
\hline & mTasheel Design Construct & Mean & SP & $\begin{array}{l}\text { Interpretati } \\
\text { on }\end{array}$ \\
\hline $\mathrm{C} 1$ & mTasheel design is attractive & 4.63 & .511 & High \\
\hline $\mathrm{C} 2$ & $\begin{array}{l}\text { The text contained in the mTasheel is } \\
\text { clearly legible }\end{array}$ & 4.58 & .629 & High \\
\hline C3 & $\begin{array}{l}\text { The images used help students to better } \\
\text { understand the content }\end{array}$ & 4.67 & .487 & High \\
\hline C4 & The colours used are eye-catching & 4.59 & .534 & High \\
\hline C5 & The font size is suitable for reading & 4.59 & .583 & High \\
\hline C6 & Easy to read writing type & 4.54 & .588 & High \\
\hline $\mathrm{C7}$ & $\begin{array}{l}\text { Clear and understandable information } \\
\text { presentation design }\end{array}$ & 4.54 & .599 & High \\
\hline $\mathrm{C} 8$ & $\begin{array}{l}\text { The design of the audio presentation is } \\
\text { clear }\end{array}$ & 4.58 & .560 & High \\
\hline C9 & $\begin{array}{l}\text { The Google application used is } \\
\text { appropriate }\end{array}$ & 4.62 & .553 & High \\
\hline & Average & 4.593 & 0.560 & High \\
\hline
\end{tabular}

\section{mTasheel Usability}

Based on Table 6.6, the interpretation of the mean score showed that the usability of mTasheel is at a high level at a mean value of 4.601 and a standard deviation of 0.553 . Three items were identified to have the highest mean score in the usability construct, namely D5 ' $m$ Tasheel is divided by units making learning more focused' $(M=4.67, S P=0.512), D 7$ 'mTasheel can be accessed at any time regardless of time and place' $(\mathrm{M}=4.67, \mathrm{SP}=0.526)$ and D8 'Repeated mTasheel training activities can improve students' understanding' ( $\mathrm{M}=$ $4.67, \mathrm{SP}=0.515)$. Followed by the D3 item 'mTasheel is easily accessible via smartphones, tablets, laptops and desktop computers' $(M=4.66, S P=0.555)$. The item that obtained a low score, i.e., item D1 ' $m$ Tasheel is easily accessible with the provided QR Code scan' ( $M=4.36$, $\mathrm{SP}=0.682$ ). In general, the usability construct recorded a high level of mean interpretation. 
Table 6: mTasheel Usability Analysis

\begin{tabular}{lccc}
\hline \multicolumn{1}{c}{ D: Usability of mTasheel } & Mean & SP & $\begin{array}{c}\text { Interpretati } \\
\text { on }\end{array}$ \\
\hline $\begin{array}{l}\text { D1 mTasheel is easily accessible with the } \\
\text { provided QR Code scan }\end{array}$ & 4.36 & .682 & High \\
$\begin{array}{l}\text { D2 mTasheel is easily accessible via the link } \\
\text { provided. }\end{array}$ & 4.64 & .509 & High \\
$\begin{array}{l}\text { D3 mTasheel is easily accessible via } \\
\text { smartphones, tablets, laptops and } \\
\text { desktop computers. }\end{array}$ & 4.66 & .555 & High \\
$\begin{array}{l}\text { D4 } \begin{array}{l}\text { The instructions for use of the module are } \\
\text { clear and easy to understand. }\end{array} \\
\begin{array}{l}\text { D5 mTasheel is divided by units making } \\
\text { learning more focused. }\end{array}\end{array}$ & 4.56 & .586 & High \\
$\begin{array}{l}\text { D6 mTasheel is divided by lesson making } \\
\quad \text { learning more focused. }\end{array}$ & 4.67 & .512 & High \\
$\begin{array}{l}\text { D7 This mTasheel can be accessed at any } \\
\text { time regardless of time and place. }\end{array}$ & 4.67 & .526 & High \\
$\begin{array}{l}\text { D8 Repeated mTasheel training activities can } \\
\text { improve students' understanding. }\end{array}$ & 4.67 & .515 & High \\
$\begin{array}{l}\text { D9 Students get immediate feedback after } \\
\text { completing the exercises provided. }\end{array}$ & 4.54 & .565 & High \\
Average & 4.601 & $\mathbf{0 . 5 5 3}$ & High \\
\hline
\end{tabular}

\section{mTasheel Impact}

The findings in Table 7 showed that the mean interpretation of the impact of mTasheel according to the respondents' views is at a high level with an overall mean value of 4.572 and a standard deviation of 0.564 . Item E5 'Students can use mTasheel especially during distance learning' ( $M=4.62, S P=0.515)$, followed by item E2 'Students can relate the content of the module to what have been learned' ( $M=4.58, S P=0.522)$, E3 'Students can build their own understanding after using mTasheel' $(M=4.57, S P=0.608)$, E1 ' Students can apply selflearning by using mTasheel ' $(M=4.56, S P=0.562)$. While the item that obtained the lowest mean value score was item E4 'Students can reflect on what they have learned through mTasheel' $(M=4.53, S P=0.612)$. However, in general all items in the impact construct were at a high level. 
Table 7: mTasheel Impact Analysis

\begin{tabular}{lccc}
\hline \multicolumn{1}{c}{ E: mTasheel Impact } & Mean & SP & $\begin{array}{c}\text { Interpretati } \\
\text { on }\end{array}$ \\
\hline E1 Students can apply self-learning by using & 4.56 & .562 & High \\
$\begin{array}{l}\text { mTasheel. } \\
\text { E2 Students can relate the content of the } \\
\quad \begin{array}{l}\text { module to what have been learned. } \\
\text { E3 Students can build their own }\end{array}\end{array}$ & 4.58 & .522 & High \\
$\quad \begin{array}{l}\text { understanding after using mTasheel. } \\
\text { E4 Students can reflect on what they have } \\
\text { learned through mTasheel. }\end{array}$ & 4.57 & .608 & High \\
E5 Students can take advantage of mTasheel \\
$\begin{array}{l}\text { especially during distance learning. } \\
\text { Average }\end{array}$ & 4.62 & .612 & High \\
\hline
\end{tabular}

\section{Discussion}

Based on the questionnaire, the findings showed that the student respondents were satisfied with all the items found in the content aspect. The item with the highest mean score was 'Visual form contents in Google Slides are appropriate to the student's level'. This was because the use of service applications provided by Google has become compatible with the majority of users. It is in line with the findings of previous studies which claimed that the use of Google applications is simple, stable and in turn can increase the level of motivation and interest of students in the learning process (Kumar et al., 2020). Next, the results showed that the content was appropriate for the student's learning duration 'The content of the module corresponds to the time allotted'. In addition, the mixing of background voice audio for dialogue and text also showed a high level of usability among students. 'Audio form contents in Google Slides are appropriate for the student's level'. While the item that obtained the lowest mean score was 'Language used is easy to understand'. Overall, the content aspect shows a high level of module usability.

The next aspect refers to the mTasheel design. There were nine items listed to the students and the item that obtained the highest mean score was 'Images used help students to better understand the content'. The researchers found that the use of images and text in learning sessions can help students to better understand the content of learning. while the two items that obtained the lowest mean scores were 'Easy-to-read writing type' and 'Clear and understandable information presentation design'. Overall, the design aspect still shows a high level of usability.

Next is the usability aspect of mTasheel. The findings showed that three items with the highest mean score, namely 'mTasheel is divided by units making learning more focused', 'this mTasheel can be accessed at any time regardless of time and place' and 'Repeated mTasheel training activities can enhance students' understanding'. The researcher found that the unit developed based on the original module is suitable for students' learning time when learning is done online. The development of mTasheel is intended to give students the freedom to learn and access learning materials whenever they need. The next item was training activities and drills that can be done repeatedly until the students are proficient with the activity. These activities and exercises use online applications such as Wordwall.net and the Google Forms 
application. Students will get immediate feedback once they have finished answering the questions displayed in the two apps.

The impact of mTasheel is the last aspect in the study of this questionnaire. The item that Obtained the highest mean score was 'Students can take advantage of mTasheel especially during distance learning.' This was because all students and teachers were facing a pandemic and require the use of online learning mediums. The use of mTasheel which uses the Google platform can help students to continue their learning sessions without facing the problems of the system server and students can access their learning materials easily without any problems. Generally, the mean score of all items in the impact aspect of mTasheel was high and showed that the students were satisfied with the learning session with the help of mTasheel as a tool to support their learning.

\section{Conclusion}

The overall findings from the first phase to the third phase in this study showed that the use of learning mediums nowadays is important because it follows the current use of technology. In 2020 alone, the number of internet users who used smartphone devices to search for information is $98.7 \%$ compared to other devices. This showed that the learning medium can be changed from a normal display-sized medium on a laptop to a smaller display to fit in a smartphone device. Students also tend to learn in a more relaxed sense and not too tied to the learning time. They are free to carry out their learning activities wherever they are and at any time. In addition, the findings also showed that students enjoy learning that uses multimedia that incorporates text, images, audio, and video in their learning sessions. Lesson notes are not only text, but animated text that is presented on a background of attractive images and colours. Additionally, there are also learning audios to guide them in their learning sessions on their own. Prompt response is also among the elements needed today, where students can get feedback at an immediate rate as soon as they finished the activity, answered the drills, and quizzes provided. The findings also showed that the use of popular services such as Google can reduce technical problems in the PdP process. Applications such as those provided by Google platforms such as Docs, Slides, Sites, Blogs, Meet, Classroom and Jamboard are among the appropriate and stable applications to be utilised in PdP sessions. These Google applications were combined with other more interactive applications to increase the attraction and motivation of students in their distance learning sessions, especially during the Covid-19 pandemic.

\section{References}

A.Rahim, N. (2013). Penggunaan mobile learning (m-learning) untuk tujuan pembelajaran dalam kalangan pelajar kejuruteraan UTHM. Universiti Tun Hussein Onn Malaysia.

Ab Ghani, F. S., \& Baharudin, H. (2016). Pendekatan 'mobile learning' dalam meningkatkan motivasi pelajar. Kolokium Pendidikan Bahasa Arab (KOBAR 2016) (pp. 194-205). Bangi: Fakulti Pendidikan, Universiti Kebangsaan Malaysia.

Ab Majid, M. R. (2017). Pengetahuan teknologi pedagogi kandungan dan kreativiti pengajaran dalam kalangan guru bahasa Arab di Malaysia. Universiti Malaya.

Abdul Ghani, K., Nik Yusoff, N. M., \& Baharuddin, H. (2010). Pembinaan modul pembelajaran kemahiran bahasa Arab di luar bilik kuliah. Kongres Pengajaran dan Pembelajaran UKM 2010. Bangi: Universiti Kebangsaan Malaysia. 
Abdul Ghani, M. T., \& Wan Daud, W. A. (2018). Arabic for Tourism Purpose via Web-based Learning. International Journal of Modern Languages and Applied Linguistics, 2(1), 610.

Agca, R. K., \& Özdemir, S. (2013). Foreign language vocabulary learning with mobile technologies. Procedia - Social and Behavioral Sciences, 83, 781-785. https://doi.org/10.1016/j.sbspro.2013.06.147

Ally, M., \& Prieto-Blázquez, J. (2014). What is the future of mobile learning in education? International Journal of Educational Technology in Higher Education, 11(1), 142-151. https://doi.org/10.7238/rusc.v11i1.2033

Che Mat, A., \& Soon, G. Y. (2010). Situasi pembelajaran bahasa asing di institut pengajian tinggi: Perbandingan antara bahasa Arab, bahasa Mandarin dan bahasa Perancis. Asean Journal of Teaching and Learning in Higher Education (AJTLHE), 2(2), 9-21.

Dahaman, A. (2014). Pembangunan modul m-pembelajaran Bahasa Arab di Institut Pendidikan Guru. Universiti Malaya.

Gill, D. J. (2006). Effects of technology on second language learning. Journal of College Teaching \& Learning, 3(2), 19-28. https://doi.org/10.19030/tlc.v3i2.1744

Goi, C. L., \& Ng, P. Y. (2009). E-learning in Malaysia: Success factors in implementing e-learning program. International Journal of Teaching and Learning in Higher Education, 20(2), 237-246.

Hamdan, A., Din, R., \& Abdul Manaf, S. Z. (2012). Penerimaan m-pembelajaran dalam sistem pendidikan di Malaysia melalui the Unified Theory of Acceptance and Use of Technology (UTAUT): Satu analisis literatur. 1st International Conference on Mobil Learning, Applications, and Services (mobilcase2012), (pp. 93-97).

Hao, Y., Lee, K. S., Chen, S., \& Sim, S. C. (2019). An evaluative study of a mobile application for middle school students struggling with English vocabulary learning. Computers in Human Behavior, 95, 208-216. https://doi.org/10.1016/j.chb.2018.10.013

Husin, N., Norul 'Azmi, N. A., \& Mat Daud, M. (2017). Pembelajaran kolaboratif melalui aplikasi telefon pintar dalam pembelajaran nahu. e-Jurnal Penyelidikan dan Inovasi, 43-63.

Hussin, S., Manap, M. R., Amir, Z., \& Krish, P. (2012). Mobile learning readiness among Malaysian students at higher learning institutes. Asian Social Science, 8(2), 276-283.

Jalil, A. G. (1993). Masalah pengajaran dan pembelajaran bahasa Arab di Maktab Rendah Sains Mara (MRSM) Terendak. Bangi: Universiti Kebangsaan Malaysia.

Jolliffe, A., Ritter, J., \& Stevens, D. (2012). The online learning handbook: Developing and using web-based learning (2nd ed.). Routledge.

Kim, D., Rueckert, D., Kim, D., \& Seo, D. (2013). Students' perceptions and experiences of mobile learning. Language Learning \& Technology, 17(3), 52-73.

Kukulska-Hulme, A., \& Shield, L. (2008). An overview of mobile assisted language learning: From content delivery to supported collaboration and interaction. ReCALL. https://doi.org/10.1017/S0958344008000335

Lim, M. R. (2014). Development of activity-based mLearning implementation model for undergraduate English language learning. Kuala Lumpur: Universiti Malaya.

Nasir, M. S., Yahaya, M. F., Abdul Hamid, M. F., \& Sahrir, M. S. (2016). Analisis respons pelajar terhadap reka bentuk laman E-Pembelajaran Bahasa Arab melalui EZ-Arabic.net untuk pelajar sekolah rendah. Jurnal Sultan Alauddin Sulaiman Shah, 3(2), 1-18. 
DEVELOPMENT

Vol. 10, No. 3, 2021, E-ISSN: 2226-6348 @ 2021 HRMARS

Nguyen, H. (2015). Modeling, designing, and implementing an ad-hoc m-learning platform that integrates sensory data to support ubiquitous learning. Florida International University.

Osman, N. (2017). Pembangunan bahan sokogan e-pembelajaran kursus bahasa Arab permulaan di UniSZA. Bangi: Universiti Kebangsaan Malaysia.

Othman, M. S., \& Ismail, M. Z. (2013). Penggunaan ICT dalam pengajaran bahasa Arab. Jurnal Linguistik, 120-127.

Pallant, J. (2020). SPSS survival manual: A step by step guide to data analysis using IBM SPSS. Routledge.

Sulaiman, R. H., \& Abdul Wahid, N. (2021). Faktor-faktor kelemahan pembelajaran balaghah. International Journal of Contemporary Education, Religious Studies and Humanities, 1(1), 111-120.

Ramli, I. (2017). Aplikasi teori mahjub dalam memperbaiki penyebutan bunyi bahasa Arab dalam kalangan pelajar Sabah. Universiti Malaya.

Saad, R. M., Ismail, Z., \& Abdullah, W. N. (2005). Pengajaran dan pembelajaran bahasa Arab berasaskan web. Kertas kerja Seminar Penyelidikan Pendidikan Maktab Perguruan Baru Lintang, (pp. 1-19).

Sahrir, M. S., \& Yusri, G. (2012). Online vocabulary games for teaching and learning Arabic. GEMA Online Journal of Language Studies, 12(3), 961-977.

Samah, R. (2012). Isu pembelajaran bahasa Arab. In M. Hamzah, K. Osman, M. Hussain, S. Zailani @ Hj. Ahmad, S. Ab. Ghani, H. Zainal, \& Z. Ismail (Ed.), Persidangan Kebangsaan Pengajaran Dan Pembelajaran Bahasa Arab 2012 (PKEBAR'12) (pp. 286-300). Bangi: Universiti Kebangsaan Malaysia.

Samu, Q. (2012). Pembentukan model keberkesanan pengintegrasian teknologi dalam pengajaran dan pembelajaran di sekolah rendah Malaysia. Universiti Malaya.

Siraj, S. (2004). Pembelajaran mobile dalam kurikulum masa depan. Masalah Pendidikan, 27(July), 129-141.

Sølvberg, A. M., \& Rismark, M. (2012). Learning spaces in mobile learning environments. Active Learning in Higher Education, 13(1), 23-33.

https://doi.org/10.1177/1469787411429189

Sopian, A. (2017). Kecenderungan pelajar terhadap pembelajaran bahasa Arab di UiTM Alor Gajah, Melaka. In M. S. Nasir, M. S. Sahrir, Z. Ab Halim, M. F. Yahaya, \& N. Mohmad Rouyan, Penataran Pendidikan Bahasa Arab di Peringkat Pengajian Tinggi (pp. 53-70). Kuala Nerus: Penerbit UniSZA.

Sundram, P. H. (2017). Using mobile phones for vocabulary acquisition in an ESL classroom. Kuala Lumpur: Universiti Malaya.

Wan Omar, W., Nasir, M., Yahaya, M., \& Ab. Halim, Z. (2016). Improving Arabic writing skills "jawlah lughawiyyah": An analysis. In M. Abdullah, W. Yahya, N. Ramli, S. Mohamed, \& B. Ahmad, Regional Conference on Science, Technology and Social Sciences (RCSTSS 2014): Business and Social Sciences (pp. 971-980). Singapore: Springer.

$\mathrm{Wu}, \mathrm{Q}$. (2014). Learning ESL vocabulary with smartphones. Procedia - Social and Behavioral Sciences, 143, 302-307. https://doi.org/10.1016/j.sbspro.2014.07.409

Yafei, O. Al, \& Osman, M. E. (2016). Mobile phone apps: An emerging e-platform for vocabulary learning and retention. Journal of Applied Linguistics and Language Research, 3(7), 286-308. 
Yahaya, M. F., Md Ghalib, M. F., \& Ab Halim, Z. (2017). Pembangunan laman e-portfolio pembelajaran bahasa Arab dengan ELGG. In M. S. Nasir, M. S. Sahrir, Z. Ab Halim, M. F. Yahaya, \& N. Mohmad Rouyan, Penataran Pendidikan Bahasa Arab di Peringkat Pengajian Tinggi. Kuala Nerus: Penerbit UniSZA.

Yahaya, M. F., Nasir, M. S., Sahrir, M. S., \& Abdul Hamid, M. F. (2016). EZ-Arabic 2.0 sebagai medium alternatif pembelajaran Bahasa Arab peringkat sekolah rendah. In A. Aziz, N. Abdul Pisal, \& Y. Yunus, Isu pendidikan bahasa Arab: aspirasi guru-autonomi pelajar (pp. 107-128). Kuala Nerus: Penerbit UniSZA.

Yaman, C. (2016). Facebook addiction levels of students in the physical education and sport department. Malaysian Online Journal of Educational Technology, 4(2), 1-7.

Zaini, A. R., Ghazali, M. R., Ismail, M. R., Zakaria, N., Hamdan, H., \& Azizan, M. R. (2017). Permasalahan dalam pengajaran bahasa Arab di Malaysia. Persidangan Antarabangsa Sains Sosial dan Kemanusiaan (PASAK 2017). Kajang: Kolej Universiti Islam Antarabangsa Selangor. 